\title{
Otel İşletmelerinde Hata Yönetiminin Psikolojik Güvenlik, Örgütsel Performans ve Örgütsel Öğrenme Üzerindeki Etkisi
}

Error Management Impact on Psychological Safety, Organizational Performance, and Organizational Learning in Hotel Management

\section{Hatice GÜÇLÜ NERGIZ*}

*Yrd. Doç. Dr., Kocaeli Üniversitesi, Turizm İşletmeciliği ve Otelcilik Yüksekokulu, Konaklama İşletmeciliği Bölümü, P. K. 41080,Derbent, Kocaeli. E-posta: hg.nergiz@kocaeli.edu.tr

\section{MAKALE BILGILERI}

Makale işlem bilgileri:

Gönderilme tarihi: 30 Aralık 2013

Birinci değerlendirme: 8 Eylül 2014

İkinci değerlendirme: 29 Ekim 2014

Üçüncü değerlendirme: 21 Kasım 2014

Kabul: 1 Aralık 2014

Anahtar sözcükler:

Hata yönetimi, Psikolojik güvenlik, Örgütsel performans, Örgütsel

ögrenme, Otel işletmeleri.

\section{ÖZ}

Bu çalışmanın amacı, otel işletmelerinde hata yönetiminin psikolojik güvenlik, örgütsel performans ve örgütsel öğrenmeye etkisini incelemektir. Bu amaç doğrultusunda, Kocaeli ili ve Sapanca ilçesinde faaliyet gösteren dört ve beş yıldızlı otel işletmelerinde araştırma yapılmıştır. Araştırmaya katılmayı kabul eden altı otel işletmesinde çalışanlara anket uygulanmıştır. Anket tekniği ile toplanan verilerde ölçek olarak Rybowiak ve diğerlerine(1999) ait olan hata yönetimi ölçeği ile Edmondson'a (1999) ait psikolojik güvenlik, örgütsel performans ve örgütsel öğrenme ölçekleri kullanılmıștır. Veriler, basit rastgele örneklem yöntemi ile araștırmaya katılan 114 kișilik bir örneklem grubundan elde edilmiştir. İlgili ölçekleri içeren soru formu ile çalışanların hata yönetimi, psikolojik güvenlik, örgütsel performans ve örgütsel öğrenmeye ilişkin algılamaları ölçülmüştür. Elde edilen veriler SPSS ve LISREL programlar kullanılarak analiz edilmiștir. Hata yönetiminin psikolojik güvenlik, örgütsel performans ve örgütsel öğrenme üzerinde etkide bulunup bulunmadığı Yapısal Eşitlik Modeli ile gerçekleştirilmiştir. Yapısal Eşitlik Modeline göre hata yönetimi ile psikolojik güvenlik arasında istatistiksel olarak olumsuz yönde bir ilişki tespit edilmiştir. Hata yönetimi ile örgütsel performans ve örgütsel öğrenme arasında ise olumlu yönde bir ilișki ortaya konulmuștur. Bu sonuçlar araştırmanın gerçekleştirildiği otel işletmelerinde çalışanların hata yönetimine ilişkin olumlu algılaması durumunda, örgütün performansının arttığı, aynı zamanda örgütsel öğrenmenin gerçekleştiği şeklinde algılandığını göstermektedir. Ancak, bunun yanında hata yönetimi ile psikolojik güvenlik arasındaki olumsuz ilișki; çalıșanların hata yaptıklarında örgütte psikolojik olarak kendilerini güvende hissetmediklerini, hata yapanların issletmede cok da hoş karşılanmadığı şeklinde algılandığını ortaya koymaktadır. Elde edilen sonuçlar doğrultusunda otel işletmesi yöneticilerine ve araştırmacılara çeşitli önerilerde bulunulmuştur.

\begin{abstract}
The aim of this study is to examine the effects error management on organization performance, psychological safety and, organizational learning in hotels. To achieve this aim, employees working in the four and five star hotels in Sapanca and Kocaeli have been conducted a survey which was adapted by the study of Rybowiak et.al. (1999) whose studies include error management scale, psychological safety of Edmondson (1999), organizational performance and organizational learning scale. By simple random sampling method, 114 employees were reached and the data obtained were analysed using SPSS and LISREL statistical programs. Whether psychological safety, organizational learning and organizational performance management has any effects on the error or not was examined by being carried out Structural Equation Model. According to Structural Equation Model, a negative relationship between error management model and psychological safety has been released. A positive relationship between organizational learning and organizational performance with error management has been determined. These results that the employees of the four and five star hotels who have conducted the survey have fallen into error when the error culture has increased and it's also obtained that learning outcomes have actualized as the result of the errors. Consequently, the performance of the staff has increased. Furthermore, the negative relation between the error management and psychological safety established that the employees don't feel psychologically safe when they have fallen into error and it has been perceived that those employees haven't been looked with favor among their colleagues. The results of the various suggestions have been made to the hotel managers and researchers.
\end{abstract}

\section{Giriş}

Örgütlerde hatalar ile karşılaşma olasılığ 1 her zaman mümkün olmakla birlikte, hata yapma olasıl1ğı, örgütün faaliyette bulunduğu sektöre göre farklılık gösterebilir. Hizmet sektöründe yer alan otel işletmelerinde ise hizmetin soyutluk, stoklanamama ve değişkenlik gibi bu işletmelerin kendine has özelliklerine ve emek yoğun bir işletme türü olmasına bağlı olarak hataların ortaya çıkma riski daha yüksektir. Argyris ve Schön (1978), örgütsel öğren- 
meyi hatanın tespit süreci ile hatanın düzeltilmesi olarak tanımlamıştır. Örgütsel öğrenme ile uyumlu olarak ifade edilen hata yönetimi kavramı özellikle emek yoğun sektör olan ağırlama endüstrisinde önem kazanmaktadır.

Hatalar; zaman kaybı, üretilen üründe istenmeyen özelliklerin olması gibi olumsuz sonuçlara (Dyck ve diğerleri 2005) sebep olmanın yanında hatalardan öğrenmenin gerçekleşmesi (Jones ve O’Brien 1991; McCune 1997) gibi olumlu sonuçları da sağlar. İşletmeler ve araştırmacılar bu olumlu yönleri arttırmak ve işletme lehine uzun vadeli yararlar elde etmek için hata yönetimi konusunda çalışmalarda bulunurlar. Hatalardan edinilen kazanımlar örgütsel öğrenmenin de sağlanmasında önemli bir etmendir. Bu faydadan yararlanabilmenin temel koşulu ise personelin yaptığı hatayı gizlemek ve kapatmaya çalışan bir yönetim tarzı yerine, hatadan zarar görmeyeceğine inanarak kendini psikolojik olarak güvende hissederek, bunu çalışma arkadaşları ile paylaşabileceği ve bu süreci bir öğrenme fırsatına dönüştürebileceği bir yönetim tarzı uygulamasıdır.

Çalışma ortamında çalışanın üstlenilen risklerin sonuçları hakkındaki algılarını ifade eden psikolojik güvenlik (Edmondson 2003: 4) algısının olumlu olması bu açıdan önem taşımaktadır. Özellikle personelin acil karar vermesi gereken ve müşteri ile birebir etkileşimde iken meydana gelen olaylar esnasında personelin işletmedeki psikolojik güvenlik algılamasının bireyin iş kalitesine ve örgütün performansına da yansıyacağı düşünülmektedir. Hataların örgütsel performans hakkında önemli bir veri kaynağı olarak ele alınmasının temel sebebi (Michael 1976; Schein 1993; Sitkin 1992), araştırmacıların hata yönetimi yaklaşımları ile örgütsel öğrenme arasındaki uyumu belirterek örgütsel öğrenmeyi; "hata bulgulama ve düzeltme süreci" (Argyris ve Schön 1978; Edmondson 1999) olarak tanımlamaları ile açıklanabilir.

Çalışanın psikolojik güvenlik algılaması yaşanılan deneyimler üzerinden kazanıldığı kabul edilerek (Edmondson 1999) ve bu algilamanın olumlu olması arzu edilir. Böyle bir durum bireyin iş kalitesine yansıyacağından bireyin performansı buna bağlı olarak da örgütsel performans yükselerek, hatalardan edinilen bilgilerle de örgütsel öğrenmenin gerçekleşeceği ifade edilebilir. Öğrenen bir örgütte hatalarla aktif olarak mücadele etmek için hatalara karşı olumlu bir tutumda sergileneceğinden (Senge 1990, Rybowiak ve diğerleri 1999: 1528) bunun olumlu sonuçlarından işletmenin fayda sağlayacağı öngörülmektedir.

Uluslararası yazında hata yönetiminin performansa etkileri (Dyck ve diğerleri 2005), psikolojik güvenlik ve öğrenme davranışı ilişkisi (Edmondson 1999; Carmeli, Brueller ve Dutton 2009), örgütsel seviyelere göre hata yönetiminin müşteri tutumuna etkileri (Guchait, Kim ve Namasivayam 2011) gibi hata yönetimi ile ilgili farklı konularda çalışmalar olduğu görülmektedir. Türkiye'de ise otel işletmelerinde hataların en aza indirilmesini hedefleyen Toplam Kalite Yönetimi gibi yaklaşımların yanı sıra, örgütsel öğrenme, örgütsel performans konularında da çok sayıda çalışma bulunmaktadır. Ancak hata yönetimi ile psikolojik güvenlik, örgütsel performans ve örgütsel öğrenme konularını tek bir çalışmada toplayarak inceleyen bir araştırmaya rastlanılmamıştır. Bu kapsamda hata yönetiminin, psikolojik güvenlik, örgütsel performans ve örgütsel öğrenme üzerindeki etkisinin ortaya konulmasına yönelik olan bu çalışmanın otel işletmelerinde yapılması, hataya açık bir işletme türü olan konaklama işletmeleri için ayrıca önem taşımaktadır. Bu ihtiyaca bağlı olarak bu çalışma, uygulanan hata yönetiminin çalışanların psikolojik güvenlik, örgütsel performans ve örgütsel öğrenmeye ilişkin algılamaları üzerindeki etkisinin belirlenmesi amacıyla gerçekleştirilmiştir.

\section{KURAMSAL ÇERÇEVE}

\section{Hata Kavramı ve Hata Yönetimi}

Otel işletmelerinde müşteri memnuniyetinin sağlanması personelin başarısına ve iş yapma kalitesine bağlı olarak gelişmektedir. Memnun edilen müşteri, otel işletmesinin devamlılı̆̆ını ve kârlılı̆̆ını sağlamasının temel unsuru olarak kabul edilmektedir. Müşteri memnuniyetinde en önemli faktör ise personelin kusursuz hizmet sunmasıdır. Otel işletmeleri sundukları hizmetlerinde kaliteyi en üst seviyeye çıkarma amacını taşırlar. Kalite yönetim yaklaşımlarından olan Toplam Kalite Yönetimi ve Altı Sigma yaklaşımlarının temelinde de hataların ortaya çımadan önce önlenmesi yer almaktadır(Kiriş 2003; Akbaba 2008: 47).

Toplam Kalite Yönetimi, müşteri gereksinimlerinin iyi şekilde karşılanması için tasarım aşama- 
sından başlayarak, üretimde, pazarlamada ve satış sonrası hizmetlerde maliyetlerin düşürülerek kalitenin yaratılması yolundaki tüm çabaları ifade eder (Genç 2007: 211). Kaliteyi sağlama yolunda en önemli iş ise hataların ortaya çıkmadan önlenmesi ve sıfır hata yaklaşımın tüm işletmede uygulanmasıdır (Akbaba 2008: 47). Toplam kalite yönetimi ile hata yönetimi yaklaşımlarının ortak noktalarının "hata" kavramı olduğu dikkat çekmektedir. Ancak, toplam kalite yönetiminde kaliteyi sağlamak için hatayı önleme ve sıfır hata yaklaşımı benimsenirken; hata yönetimi yaklaşımında hataların tamamen önlenemediği kabul edilerek, yapılan hatalardan yararlanılarak bunun bir fırsata dönüştürülmesi benimsenmiştir.

Kalite yönetim yaklaşımlarından biri de Altı Sigma yaklaşımıdır. Bu yaklaşım, işletmenin bütününde hataları, maliyetleri, çevrim zamanını azaltmayı; verimliliği ve kaliteyi arttırmayı, israfları ortadan kaldırmayı ve değişkenlikten kurtulmayı hedefleyen bir felsefedir (Kiriş 2003). Diğer bir ifade ile Altı Sigma aslında sıfır hata stratejisinin yaşama geçirilmesini hedefleyen istatistiksel bir kontrol düzeneğidir (Esenkal 2006: 42). Görüldüğü gibi hata yönetimi, toplam kalite yönetimi ve altı sigma yöntemlerinden hatalardan yararlanmayı hedeflemesi yönü ile farklı bir anlayış çizen bir yöntem özelliği göstermektedir. Bu yönü ile farklı bir yönetim yaklaşımı olan hata yönetimi yaklaşımının önemi, bu çalışma ile ortaya konabilecektir.

Ancak, en başarılı otel işletmelerinin bile hataların önlenmesinde zorluklar yaşayabileceği düşünülmektedir. Bu sebeple otel işletmelerinde hatalar oluştuğunda, bu durumun müşterilere doğrudan yansıması durumunda müşteri memnuniyetsizliği ortaya çıkabilmektedir. Bu durumdan etkilenme olasılığında olan diğer taraf ise otel personelidir. Özellikle müşterilerle birebir etkileşimde bulunan personelin hata yapması durumunda işten atılacağ1 yönünde bir endişesinin olması, personelin kendisini psikolojik olarak güvende hissetmemesine ve bu algıya sahip personelin bu kaygıları işine yansıtarak, verim düşüklüğ̈ü, iş kalitesinin azalması ve devamında işten ayrılma eğiliminin ortaya çıkması gibi durumlara sebep olabilecektir. Hata konusu ile yakından ilgilenen araştırmacılar hata kavramını; "zihinsel veya fiziksel olarak planlanarak bir dizi halinde sıralanmış faaliyetlerin yürütülmesi esnasında amaçlanan sonuca ulaşmada sapmaların meydana gelmesi" (Reason 1990: 9) olarak ifade etmişlerdir. Bu çalışmalarda ifade edilen önemli bir nokta, örgütte uygulanacak hata yönetimi ile yapılan hatalara ilişkin hazırlanacak karşılaştırılabilir hata formlarının işaret ettiği kritik noktaları belirleyerek (iletişim, onaylama, yargılama, karar alma, yorumlama gibi) bunlardan elde edilen bulguların yeni hataların önlenmesinde kullanılabilmesidir (Rasmussen 1982). Böylece otel yöneticileri için önemli bir geribildirim kaynağı olan hatalar ve hata sonrasında elde edilen öğrenme kazanımının gerçekleşmesi sağlanabilir.

Hataların kolayca tanımlanamaması (Senders ve Moray 1991), örgütte belirlenen amaçlar, standartlar, davranışlarda plansız sapmaların (Dyck ve diğerleri 2005: 1229) meydana gelmesine sebep olmaktadır. Örgütler, çoğunlukla hataları sadece önleme üzerine odaklanır. Sadece hata önlemeye yönelik yaklaşımlar öğrenmenin meydana gelmesine izin vermediğinden (Sitkin 1996), öğrenme stratejilerinden deneme yaklaşımı (Huber 1991)ile kontrol sürecinde hatayı önleme amacı doğrudan çatışma içindedir. Bunun tersine, ilgili yazında daha çok genel öğrenme amacı ile örgütsel hata yönetim yaklaşımları kavramsal olarak ilişkilendirilir (Dyck ve diğerleri 2005: 1229). Otel yöneticilerinin hatanın önlenemez olduğunu kabul ederek, hata yönetim yaklaşımının öğrenmenin gerçekleşmesine katkıda bulunduğunu ve bu görüşün hata yönetimi eğitimi konusunda yapılan araştırmalarda da desteklendiğini (Frese 1995; Nordstrom, Wendland ve Williams 1998) kabul ederek, bu durumun bir firsat olarak görülmesi gerekir. Bunun için örgütlerde hataların meydana gelmesi durumunda personelin yönetimin bu durumu nasıl karşıladı̆̆ı ile ilgili algılaması, bu algılamaya bağlı olarak personelin kendisini güvende hissedip hissetmemesi, bunun örgütün performansına yansımaları ile örgütsel öğrenmenin gerçekleşip gerçekleşmeyeceği üzerinde düşünülmesi gereken konuların başında gelmektedir.

İnsan hatalarının tipik bir çerçevesini çizebilmenin mümkün olmaması (Korsten, Stanz ve Blignaut 2004: 38), hataların tanımlanmasını ve hataları ortaya çıkaran sürecin sebeplerini belirlemeyi güçleştirmektedir. Bu zorluklara rağmen, hataların öğrenme, yenilik ve esneklik gibi uzun dönemli olumlu etkilerinden (Sitkin 1996) yararlanma amac1, araştırmacıların hataları inceleme konusu yapmalarının temel sebeplerinden biridir. Otel işletmelerinde 
hatalar konusunda etkili yaklaşım uygulayan yöneticiler uzun vadede elde ettikleri bu olumlu sonuçların sağladığı deneme yapma ve yeniliklerde bulunabilme avantajı ile işletmelerinin daha kârlı bir duruma gelmesine katkıda bulunabileceklerdir.

Hataların olumsuz etkilerini azaltarak, olumlu yönlerinden daha fazla yararlanmak için hata yönetiminin kullanılması gerekir. Hata yönetimi yaklaşımı, insan hatalarının asla tamamen önlenebilir olmadığını kabul ederek, hatalar meydana geldikten sonra "ne oldu ve ne yapilabilir", sorusunun sorulması gerektiğini varsayar (Frese 1991, 1995). Hata yönetimi yaklaşımı, hatalar ve sonuçları arasındaki farkları anlamaktır. Bu yönetim tarzı, hataların olumsuz sonuçlarını azaltmaya ve potansiyel olumlu sonuçlarını arttırmaya odaklanan bir yaklaşım sergilemeyi kabul eder (Dyck ve diğerleri 2005: 1228).

Hata yönetiminin bulunduğu bir örgüt kültüründe çalışanların psikolojik güvenlik algılamaları yüksek düzeydedir. Çalışanların psikolojik güvenlik algılamalarının olumlu olması ise örgütsel performansın arttırılması açısından önem taşımaktadır. Hatalar hakkında konuşulması ve çalışanların cezalandırılmayacaklarını bilmeleri, bir hata yapılması durumunda çalışanların bunu bir öğrenme fırsatı olarak algılamalarını sağlayacaktır. Hatalar, örgütsel öğrenmenin en önemli arka plan değişkenlerinden biri olabilir. Çünkü örgütün hatalarla ilgilenmesi örgütsel öğrenme düzeyini belirleyen bir araçtır. Hatalar, performansı en iyi yönlendiren öğrenme geliştiricisi (Dormann ve Frese 1994) olarak da kullanılarak, örgütsel etkililiğin artmasına (Argyris 1990) da katkıda bulunur. Bu bağlamda, bir örgütte örgütsel öğrenmeye ulaşmak hedefleniyorsa hatalar, pasif yaklaşımlardan daha çok aktif yaklaşımlar kullanılarak (Frese 1995), diğer bir ifadeyle hatanın önlenemez olduğu ve hatadan edinilebilecek kazanımlar bulunduğu şeklinde bir görüşün benimsenmesi gerekir.

Hata yönetimi çalışmalarında en sık kullanılan ve kabul gören hata yönetimi boyutları Rybowiak ve diğerleri (1999) tarafından önerilen ve sekiz boyuttan oluşan modeldir. Bu boyutlar; hata yeterliliği, hatalardan öğrenme, hatalardan risk alma, hata gerginliği, hata tahmini, hataları örtbas etme (kapatma), hata iletişimi ve hatalar hakkında düşünmedir.
Hata Yeterliliği: Hatalar meydana geldiğinde hataların üstesinden gelebilmek için gereken bilgi ve yeteneği ifade eder. Bu sebeple kısa vadeli amaçlar tarafından yönlendirilir ve hata yeterliliği ile başarısızlık sonrasındaki faaliyet oryantasyonu arasında olumlu ilişki aranır (Rybowiak ve diğerleri 1999).

Hatalardan Öğrenme: Hatalardan uzun vadedeki gelecek için bir şeyler öğrenme anlamına gelir, böylece çalışma planları uzun vadede mükemmele ulaştırilir.

Hatalardan Risk Alma: Hatalardan risk almada iki teorik beklenti vardır. Birincisi, hatadan risk alma genel esnekliği ve hatalar doğrultusunda açıklı̆̆ ifade eder. Bu sebeple değişime hazır oluşla arasında olumlu ilişki vardır.

Hata Gerginliği: Hata yapmaktan, hataların oluşumundan korkmayı ve hatalara fazla duygusal tepki göstererek gergin olma durumunu ifade eder.

Hata Tahmini: Hatalarla ilgili iki beklenti vardır. Birincisi, gerçekçi bir görünümü ifade eder, kişinin uzmanlık alanında bile olsa hatalar meydana gelebilir. Bu açıdan ele alındığında hata yetkinliği ile öğrenme arasında olumlu ilişki olmalıdır (Rybowiak ve diğerleri 1999: 534-535). Genel karamsarlık, özgüven eksikliği ve olumsuz duygusallığın bir sonucu olarak istikrarlı olumsuz bir tutumda hatalar meydana gelir.

Hataları Örtbas Etme (Kapatma): Endişeli insanların hataları bir tehdit olarak kabul ederek hataları ile ilgili konuları örtbas ederek konunun kapatılmasıdır (Rybowiak ve diğerleri 1999: 535).

Hata İletişimi: İletişim, hata yönetiminde yer alan en önemli boyutu ifade etmektedir. Yüksek düzeyde iletişimin olduğu bir örgütte hatalar hakkında yapılan görüşmeler, hatalarla ilgili bilginin paylaşılmasına da imkân sağlar. Ayrıca, hata iletişimi yüksek riskli durumlarda hatalara karşı strateji geliştirilmesi için de önemli kolaylıklar sağlar (Mathieu ve diğerleri 2000).

Hatalar Hakkında Düşünme: Hatalar meydana geldikten sonra hatanın analiz edilmesi de hatadan olumlu sonuçlar alınması yönünde önemli bir aşamayı oluşturur.

Bu bilgilere dayanarak, hata yönetimi boyutlarının hata yönetimi üzerindeki etkilerini belirlemek amacı ile oluşturulan H1 hipotezleri aşağıdaki şekilde ifade edilmiştir: 
H1a:: Hata yeterliliği hata yönetimi üzerinde etkilidir.

$H 1 b::$ Hatalardan öğrenme hata yönetimi üzerinde etkilidir.

H1c:: Hatadan risk alma hata yönetimi üzerinde etkilidir.

H1d:: Hata gerginliği hata yönetimi üzerinde etkilidir.

H1e:: Hata tahmini hata yönetimi üzerinde etkilidir.

H1f:: Hataları örtbas etme hata yönetimi üzerinde etkilidir.

H1g: Hata iletişimi hata yönetimi üzerinde etkilidir.

H1h:: Hatalar hakkında düşünme hata yönetimi üzerinde etkilidir.

\section{Psikolojik Güvenlik}

Psikolojik güvenlik, çalışanın konu hakkında soru sorması, bir hatanın bildirilmesi, geribildirim istenmesi ve yeni bir fikrin ileri sürülmesi gibi durumlarda nasıl bir cevap alınacağına dair inançlaridır (Edmondson 2003: 4). Kahn (1990),psikolojik güvenlik kavramını: "Personelin işiyle ilgili kişisel izlenimi, rolü ya da kariyeri için olumsuz sonuçlar olmayacağına dair korkusu olmadan kişinin işinde çalışmasına ilişkin duyguları" olarak ifade etmiştir. Son görgül araştırmalar psikolojik güvenliğin işle bütünleşmeyi desteklediğini ortaya koymuştur (May, Gilson ve Harter 2004). Benzer şekilde, örgütsel değişim üzerine yapılan bir araştırmada psikolojik güvenlikle nitelendirilen çalışma çevresinin bireylerin kendilerini güvenli hissetmeleri için gerekli olduğunu, böyle bir ortamın da davranışın değiştirilmesini sağlayacağını ileri sürmüşlerdir (Schein ve Bennis (1965) akt: Edmondson 2003:4).

Schein (1985: 298-299), psikolojik güvenliğin “öğrenme kaygıları"nın üstesinden geldiğini, insanların beklentilerinin onaylanmadığını bilmeleri durumunda verimli öğrenme davranışının engellendiğini savunmuştur. Çalışanların psikolojik güvenlik algılamalarının yüksekliği öğrenme davranışını kolaylaştırır. Carmeli, Brueller ve Dutton (2009), lisans ve yüksek lisans öğrencileri arasında yaptıkları bir araştırmada, yüksek kaliteli ilişki kapasitesi ile psikolojik güvenlik ve örgütsel öğrenme arasındaki ilişkileri incelemişlerdir. Bulgulara göre yüksek kaliteli ilişki deneyimleri ile psikolojik güvenlik arasında istatistiksel olarak olumlu bir ilişki olduğu ortaya çıkmıştır. Ayrıca, psikolojik güvenlik ile örgütsel öğrenme arasında da istatistiksel olarak olumlu ilişki bulunmuştur. Otel işletmelerinde psikolojik güvenliğin örgütsel öğrenme ve hata yönetimi üzerinde etkili olup olmadığı konusu çalışılmamıştır. Bu durum aşağıda geliştirilen hipotezler ile sınanacaktır.

H2. Psikolojik güvenlik hata yönetimi üzerinde etkilidir.

H3. Psikolojik güvenlik örgütsel öğrenme üzerinde etkilidir.

\section{Örgütsel Performans}

Belirlenen hedeflere ulaşma seviyesi olarak ifade edilebilecek olan performans kavramının alanyazında etkinlik, etkililik, verimlilik gibi kavramlarla birlikte kullanıldığı görülmektedir (Avcı ve Topaloğlu 2008: 339). Performans, üretilen işin kalite ve miktarını ifade eden genel bir kavramdır (DuBrin 1986: 372). Farklı şekillerde tanımlansa da performans, hedefe ulaşma düzeyi ile ilgilidir (Dwight 1999). Örgütün amaçlarının gerçekleştirilmesi için gösterilen çabaların değerlendirilmesini ifade eden örgütsel performans, işletme ile ilgili ve genellikle sayısal bilgileri oluşturan göstergeler yardımıyla ölçülebilir (Avcı ve Topaloğlu 2008: 341).

Aydoğan ve Deniz (2013) Nevşehir'de bulunan otel işletmelerinde sosyo-teknik kolaylaştırıcılar olan güven, içsel ve dışsal ödül ile bilgi yönetim sisteminin, bilgi paylaşımı ve örgütsel performans üzerindeki etkilerini araştırmıştır. Buna göre; güven ile bilgi paylaşımı niyeti, davranışı ve örgütsel performans arasında istatistiksel olarak olumlu yönlü bir ilişki tespit edilmiştir.

Örgütsel performansın ölçülmesinde geleneksel yöntemlerde kullanılan finansal verilerin kısa vadeli ve geçmişe dayalı verilerden oluşması gibi sınırlılıklar performans ölçümünü güçleştirmektedir. Bu sebeplerle bu çalışmada, araştırma alanı olarak seçilen otel işletmelerinin dinamik bir çevrede faaliyet göstermesinden ve diğer performans ölçüm yöntemlerinin uygulanma zorluklarından dolayı örgütsel performansın temel belirleyicisi olarak çalışanların örgütün performansını algılama düzeylerinin ele alınması gerektiği üzerine odaklanılmıştır. Ayrıca, çalışmada hata yönetimi ile psikolojik güvenlik, örgütsel performans ve örgütsel öğrenme arasındaki ilişkiyi ortaya koymak hedef- 
lendiğinden bu temel amaca hizmet edecek şekilde tüm işletme düzeylerinde öğrenme sürecinde bilgi altyapısını arttıran bir araç olarak örgütsel performans konusu ele alınmıştır. Bu bilgilere dayanarak örgütsel performansın örgütsel öğrenme ve hata yönetimi üzerindeki etkilerini belirlemek amacıyla aşağıdaki hipotezler geliştirilmiştir:

H4. Örgütsel performans örgütsel öğrenme üzerinde etkilidir.

H5. Örgütsel performans hata yönetimi üzerinde etkilidir.

\section{Örgütsel Öğrenme}

Öğrenme, bilgi ve tecrübe sonucu davranışta oluşan sürekli değişimi ifade eder (Eren 2008: 598). March ve Olsen (1975), örgütlerin deneyimlerine göre hareket tarzlarını değiştirmesine dayanan öğrenmeyi "örgütsel öğrenme" olarak ifade etmiştir. Levitt ve March (1988: 320), örgütsel öğrenmeyi tarihten çıarımlar yaparak rutin davranışlara rehberlik eden örgütsel bir süreç çıtısı olarak tanımlamışlardır. Örgütsel öğrenme konusunda önemli çalışmalarda bulunan Argyris ve Schön (1978) ise örgütsel öğrenmeyi hata tespit ve düzeltme süreci olarak ifade etmiştir. Tek döngülü ve çift döngülü olarak iki türe ayrılan örgütsel öğrenme, hatalardan öğrenmenin gerçekleşmesi ile birlikte ifade edilir. Tek döngülü öğrenmede, reaktif bir yaklaşım söz konusudur, bakış açısı yüzeyseldir ve öğrenme, hata gerçekleştikten sonra ortaya çımaktadır. Çift döngülü öğrenme ise örgütsel öğrenmenin üretken ya da yaratıcı tarafını oluşturur. Sorunları derinlemesine inceler, sistemi ve hataların neden kaynaklandığını sorgulayan bir özelliğe sahiptir (Arslantaş 2006: 53).

Öğrenme ile örgütler karşılaştıkları değişimlere uyum sağlayarak, aynı hataları tekrarlamayacak şekilde gereksinim duydukları bilgileri depolar, bunlardan yararlanarak davranışlarını ve hareket tarzlarını değiştirirler (Avcı ve Küçükusta 2009: 34).

Bireyler içinde bulundukları ve faaliyet yaptıkları örgütün çalışma biçiminden ve örgütün uygulamakta olduğu faaliyet ve süreçlerinden çıkarımlarda bulunurlar. Çalışanlar kendilerine göre hatalı yönleri bularak örgütsel öğrenme faaliyetini gerçekleştirirler. Hataları düzeltmek için harekete geçmeleri ile örgütsel öğrenme somut olarak ortaya ç1kar (Eren 2008: 599). Bu sebeple örgütsel öğrenme, çalışmanın konusunu oluşturan hata yönetiminin de temelini oluşturmaktadır.

Avcı ve Küçükusta (2009), Çeşme'de beş yıldızlı otel işletmelerinde örgütsel öğrenme uygulamalarının örgütsel bağlllık ve işten ayrılma eğilimi üzerindeki etkilerini araştırmışlardır. Araştırma sonucunda, örgüt düzeyinde gerçekleşen öğrenmenin örgütsel bağl1lığı olumlu yönde etkilediği, örgütsel öğrenme ile işi bırakma eğilimi arasında ise olumsuz yönde ilişki bulunmuştur. Bu araştırma sonu$\mathrm{cu}$ da otel işletmelerinde en önemli rekabet unsuru olan insan unsurunun işletmeye bağlanması ve işten ayrılma eğiliminin düşürülmesinde örgüt düzeyinde gerçekleştirilecek olan öğrenmenin önemli bir yönetim yaklaşımı olduğunu desteklemektedir.

Avc1, Kılınç ve Okumuş (2010), Muğla ilindeki beş yıldızlı otel işletmelerinde bireysel öğrenme, takım öğrenmesi ve örgütsel öğrenme arasındaki ilişkiyi incelemiştir. Buna göre, bireysel öğrenme ile örgütsel öğrenme arasındaki ilişki eğitim ve geliştirme, sürekli iyileştirme, yönetimin tutum ve desteği faktörleri tarafından açılanmaktadır. Takım öğrenmesi ile örgütsel öğrenme arasındaki ilişkiyi ise eğitim ve geliştirme, sürekli iyileştirme, yönetimin tutum ve desteği, inisiyatif kullanma faktörlerinin açıkladığı saptanmıştır. Öğrenme düzeyleri arasındaki ilişkiyi en güçlü açıklayan değişken ise eğitim ve geliştirme faktörüdür.

Avc1 (2005), performans, örgütsel performans ve örgütsel öğrenme arasındaki ilişkide; yönetimin tutumu, eğitim ve geliştirme faaliyetleri ile açık fikirliliğin örgütsel öğrenmede önemli olduğunu saptamıştır. Örgütsel öğrenme ile finansal olmayan performans arasında da (Çalışma Yaşam Kalitesi ve Yenilik) önemli bir bağlantı olduğu tespit edilmiştir.

\section{ARAŞTIRMA YÖNTEMI}

\section{Araştırmanın Amacı ve Önemi}

Bu çalışmanın temel amacı, hata yönetiminin psikolojik güvenlik, örgütsel performans ve örgütsel öğrenmeye etkisini incelemektir. Bu temel amaç kapsamında dışsal faktör olarak belirlenen hata yönetimi ile içsel faktörler olarak belirlenen psikolojik güvenlik, örgütsel performans ve örgütsel öğrenme arasındaki ilişkilerin yanı sıra içsel faktörlerin birbirleriyle olan ilişkilerini analiz etmek hedeflenmiştir. Bununla birlikte modelde yer alan 
faktörleri en iyi açılayan ve modelde en etkili olan değişken(ler) de belirlenmektedir. İşletmede uygulanan hata yönetimi yaklaşımına bağlı olarak çalışanların psikolojik güvenlik algılamalarının farklılık göstermesi, buna bağlı olarak örgütsel performanslarının etkilenmesi, örgütsel öğrenmenin gerçekleşmesi ya da gerçekleşmemesi söz konusudur. Bu anlamda, hata yönetimi bağımsız değişken, psikolojik güvenlik, örgütsel performans ve örgütsel öğrenme bağımlı değişkenler olarak tanımlanmıştır. Önceki çalışmalarda hata yönetimi ile ilişkili olan bu unsurların birbirinden bağımsız şekilde araştırılması nedeni ile hata yönetimi sonucunda gerçekleşen öğrenme sürecinin hangi faktörlerin etkisinde gerçekleştiğine ve bu faktörlerin birbiri arasındaki ilişkisine dair bir değerlendirme yapmak mümkün olamamaktadır. Bu araştırma, hata yönetimini açılayan tüm boyutların değerlendirilerek, ilgili diğer faktörler arasında karşılaştırma yapma ve faktörlerin birbirleriyle olan ilişkilerini ortaya koyma açısından da özgün bir çalışma olarak değerlendirilebilir.

Farklı sektörlerde yapılan araştırmalar (Ellis ve diğerleri 1999; Putz ve diğerleri 2013; Guchait, Pasamehmetoğlu ve Dawson 2014) olmasına rağmen, doğrudan çalışma konusunun tümünü kapsayan bir araştırmanın olmaması, bu çalışmanın çıkış noktasıdır. Bununla birlikte çalışma, otel işletmelerine odaklanmaktadır. Çalışma, hem teorik hem de Kocaeli ve Sapanca'da bulunan otel işletmelerine yönelik pratik bulgular ve sonuçlar elde edilmesine yardımcı olabilecektir. Çalışanların çok sık iş değiştirdiği ve bu değişimin müşteri memnuniyetine bile etki ettiği otel işletmelerinde direkt olarak çalişanlara olumlu bir iş ortamı yaratabilen işletmeler rekabet avantajı sağlayabilecektir. Çalışanların işten ayrılmasına sebep olan tüm olumsuzlukların ortadan kaldırılması, bir hizmet işletmesi olan oteller için ayrı bir öneme sahiptir. Personelin çalıştı̆̆ 1 ortamda kendini güvende hissetmesini ifade eden psikolojik güvenliği olumsuz etkileyen unsurların ortadan kaldırılması da bu açıdan önemlidir.

\section{Araştırma Modeli}

$\mathrm{Bu}$ çalışmada, örgütlerde uygulanan hata yönetiminin; bireylerin psikolojik güvenlik, örgütsel performans ve örgütsel öğrenme algılamalarına etkisi incelenmiştir. Zira örgüt içindeki hata yönetiminin uygulanmaması, bireylerin işteki psikolojik güven- lik algılamalarının düşük olmasına, örgütsel performansın düşmesine ve örgütsel öğrenmenin gerçekleşmemesine neden olabilmektedir. Bununla birlikte, örgüt içindeki hata yönetimini ifade eden hata yeterliliği, hatalardan öğrenme, hatadan risk alma, hata gerginliği, hata tahmini, hataları örtbas etme, hata iletişimi ve hatalar hakkında düşünmenin olumsuz olması da bireyin hata yönetimi alg1laması üzerine olumsuz yönde etkili olabilmektedir. Bu düşünceden hareketle çalışmada; hata yönetimi boyutlarının psikolojik güvenlik ve örgütsel performans üzerindeki etkileri incelenmiş, aynı zamanda psikolojik güvenlik ve örgütsel performansın örgütsel öğrenme üzerindeki etkileri de araştırılmıştır. Değişkenlerin birbiri arasındaki ilişkiyi belirlemek amacı ile oluşturulan çalışmanın yapısal modeli Şekil 1 üzerinde gösterilmektedir:

\section{Araştırmada Kullanılan Veri Toplama Araçları}

Verilerin toplanmasında, demografik bilgiler dışında, çalışanların hata yönetimi, psikolojik güvenlik, örgütsel performans ve örgütsel öğrenme algı düzeylerini belirlemek amacıyla dört ayrı ölçekten yararlanılmıştır. Çalışanların demografik bilgilerini toplamaya yönelik olan kısımda cinsiyet, yaş, medeni durum, eğitim durumu, kıdem durumu ve çalışılan bölüm gibi özellikler yer almaktadır. Anket formunda katılımcıların demografik özelliklerini ölçen 12 adet kapalı uçlu soru yer almıştır.

Hata yönetimi algılamasını ölçmek için Rybowiak ve diğerleri (1999) tarafından geliştirilen ölçekten yararlanılmıştır. Hata yönetimi ile ilgili 37 (hata yeterliliği dört, hatalardan öğrenme dört, hatalardan risk alma dört, hata gerginliği beş, hata tahmini beş, hataları örtbas etme altı, hata iletişimi dört, hatalar hakkında düşünme beş)ifadeye yer verilmiştir. Edmondson (1999) tarafından ge-

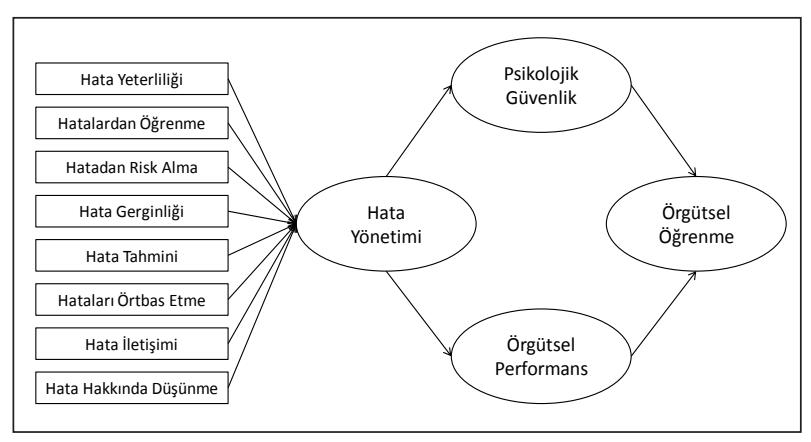

Şekil 1. Araştırma Modeli 
liştirilen ve psikolojik güvenlik (altı ifade), örgütsel performans (dört ifade) ve örgütsel öğrenmeyi (yedi ifade)ölçmeye yönelik olarak hazırlanan soru formundan yararlanılmıştır. Orijinal ölçeklerin yazar tarafından Türkçeye çevrilmesinin ardından, İngilizce okutmanları ve turizm alanındaki akademisyenlerin kontrolü sonrasında ölçeğe son şekli verilmiştir.

Ölçümde beşli Likert tipi ölçek kullanılmıştır ( $1=$ Kesinlikle katılmiyorum, 5= Kesinlikle katıl1yorum). Türkçeye çevrilen ölçeğin her bir ifadenin yanlış açıklanması ve anlaşılırlıkta hata yapılma ihtimaline karşın pilot uygulama yapılmıştır. Pilot uygulama Kocaeli Üniversitesi Turizm İşletmeciliği ve Otelcilik Yüksekokulu Konaklama İşletmeciliği Bölümü 4. sınıf öğrencilerine uygulanmıştır. Sektör deneyimine ve konaklama işletmelerinde staj yapmış olmaları sebebi ile pilot çalışmada bu öğrencilerin katılımları sağlanmıştır. Pilot uygulama sonrasında ölçekte anlaşılmayan ifadeler düzeltilerek, ankete son şekli verilmiştir.

\section{Araştırmanın Evreni ve Örneklemi}

Araştırmanın evrenini Kocaeli ili ve Sapanca ilçesindeki 16 adet dört ve beş yıldızlı otel işletmeleri oluşturmaktadır. Kocaeli'de üç adet beş yıldızlı, on adet dört yıldızlı; Sapanca'da ise iki adet beş yıldızlı ve bir adet dört yıldızlı otel bulunmaktadır. Otellerin insan kaynakları ve ilgili diğer yetkilileri ile telefon görüşmeleri yapılarak, çalışma hakkında bilgi verilmiş sonrasında araştırma için izin istenmiştir. Otellerden biri müşteri yoğunlukları sebebi ile araştırmaya katılmayı kabul etmemiştir. İki otel işletmesi ise araştırmayı kabul etmelerine rağmen, anketleri iade etmemişlerdir. Diğer altı otel işletmesi ise neden belirtmeden araştırmaya katılmayı kabul etmemiştir.

Araştırma, Kocaeli'de üç adet beş yıldızlı ve üç adet dört yıldızlı olmak üzere toplam altı otelde; Sapanca'da ise bir adet beş yıldızlı otel işletmesindeki çalışanlar arasında gerçekleştirilmiştir. Araştırmaya katılan otel işletmelerinde çalışan sayısı toplam 460 kişidir. Araştırmaya katılacak otel işletmelerinden ne kadar örneklem alınacağının belirlenmesinde evrendeki örneklem sayısının bilinmesi durumunda kullanılan tablodan (Ural ve Kılıç 2011: 47) yararlanılarak örneklem sayısı 210 kişi olarak belirlenmiştir. Araştırma evrenini temsil edecek örneklemi belirlemede olasılıklı örneklem yöntemlerinden "basit tesadüfi örnekleme yöntemi" kullanılmıştır. Araştırma Nisan ve Haziran 2013 tarihleri arasında gerçekleştirilmiştir. Araştırmaya katılmayı kabul eden işletmelere çalışan sayısına göre anketler insan kaynakları departmanına bırakılarak, bu bölüm aracılığ 1 ile anketlerin tamamlanması sağlanmıştır. Dağıtılan 410 anketten geri dönen toplam 124 anketin 10'unda çok sayıda cevaplandırılmamış soru olduğu için bu anketler elenmiş ve analize dahil edilmemiştir. Böylece, araştırma verilerinin analizi 114 anket üzerinden yürütülmüştür. Araştırma için örneklem sayısı 210 olarak belirlenmişti. Geri dönen 114 anketin analizi ile evrenin $\% 54$ 'üne ulaşılmıştır.

\section{Araştırma Verilerinin Analizi}

Araştırma verilerinin analizinde parametrik testlerin uygulanabilmesi için verilerin aralık seviyesinde ölçülmüş olması gerekir. Bunun yanı sıra, veri normal veya normale yakın bir dağılım göstermeli; bütün gruplar normal dağılım gösteren, ana kütleden gelmiş olmalı ve hata terimleri tesadüfî olarak birbirinden bağımsız olmalıdır (Yazıcığlu ve Erdoğan 2004: 155-156). Araştırma verilerinin bu koşulları sağladığından araştırmada parametrik testlerin uygulanmasına karar verilmiştir.

Elde edilen verilerin araştırma modeline uygunluğu, Lisrel doğrulayıcı faktör analizi ve yapısal eşitlik modeli (LISREL 8.7) ile test edilmiştir. Araştırmanın hipotezlerini test edebilmek amaciyla, Yapısal Eşitlik Modeli (YEM) uygulanmıştır. Jöreskog ve Sorborn (1973) tarafından sosyal bilimler alanına uygulanan ve Bentler (1980) tarafından psikoloji alanında ayrıntılı olarak betimlenen "gizil değişken analizi" çok sayıda gözlenen ya da ölçülen değişken tarafından temsil edilen "gizil (latent)" yapıları içeren çok değişkenli istatistik analizleri tanımlamak için kullanılmıştır (Güllülü ve diğerleri 2008: 117).

\section{BULGULAR}

Araştırmaya katılanlara ait demografik özelliklere ilişkin bulgular Tablo 1'de görülmektedir.

\section{Araştırmada Kullanılan Ölçeklerin Doğrulayıcı Faktör Analizi}

Araştırmada kullanılan hata yönetimi, psikolojik güvenlik, örgütsel performans ve örgütsel öğrenme faktörlerinin altında yer alan değişkenler teorik 
Tablo 1. Demografik Özelliklere İliş̧kin Sayısal ve Yüzdesel Dağılım Tablosu

\begin{tabular}{lrr}
\hline Değişkenler & $n$ & $\%$ \\
\hline Cinsiyet( $n=109)$ & & \\
Kadın & 43 & 37,7 \\
Erkek & 66 & 57,9 \\
Boş & 5 & 4,4 \\
\hline Yaş (n=114) & & \\
$18-25$ & 32 & 28,1 \\
$26-33$ & 56 & 49,1 \\
$34-41$ & 15 & 13,2 \\
$42-49$ & 6 & 5,3 \\
$50-57$ & 1 & 0,9 \\
58 ve üstü & 1 & 0,9 \\
Boş & 3 & 2,6 \\
\hline Medeni Durum (n=111) & & \\
Bekâr & 51 & 44,7 \\
Evli & 58 & 50,9 \\
Boşanmış & 2 & 1,8 \\
Boş & 3 & 2,6 \\
\hline
\end{tabular}

\begin{tabular}{lrr}
\hline Eğitim Durumu $(n=112)$ & & \\
Okuryazar & 3 & 2,6 \\
İlkokul & 8 & 7,0 \\
Ortaokul & 15 & 13,2 \\
Lise & 37 & 32,5 \\
Üniversite & 45 & 39,5 \\
Lisansüstü & 2 & 1,8 \\
Boş & 4 & 3,5 \\
\hline Kıdem Durumu $(n=113)$ & $\mathrm{n}$ & $\%$ \\
1'den az & 33 & 28,9 \\
1-5 & 33 & 28,9 \\
$6-10$ & 39 & 34,2 \\
$11-15$ & 6 & 5,3 \\
16 ve üstü & 2 & 1,8 \\
Boş & 1 & 0,9
\end{tabular}

\begin{tabular}{lrr}
\hline Çalışılan Bölüm $(n=114)$ & & \\
Önbüro & 21 & 18,4 \\
İnsan Kaynakları & 4 & 3,5 \\
Satınalma & 3 & 2,6 \\
Yönetim & 1 & 0,9 \\
Satış-Pazarlama & 5 & 4,4 \\
Mutfak & 17 & 14,9 \\
Kat Hizmetleri & 14 & 12,3 \\
Muhasebe & 6 & 5,3 \\
Güvenlik & 8 & 7,0 \\
Halkla İlişkiler & 2 & 1,8 \\
Çamaşırhane & 2 & 1,8 \\
Servis & 15 & 13,2 \\
Teknik Servis & 2 & 1,8 \\
Bar & 2 & 1,8 \\
SPA & 6 & 5,3 \\
Diğer & 6 & 5,3 \\
Boş & 3 & 2,6 \\
\hline
\end{tabular}

olarak tutarlılık ve uygunluk bakımından incelenmiştir. Araştırmada öncelikle ölçekleri test etmek amacıyla doğrulayıcı faktör analizi yapılmıştır. Olumsuz varyans gösteren, standart katsayıları aşan (1,0'e çok yakın) ya da çok büyük standart hata veren değişkenler kontrol edilmiş (Hair vd. 1998) ve uygun olmayan değişkenler elenmiştir.

\section{Psikolojik Güvenlik, Örgütsel Performans ve Örgütsel Öğrenme Ölçeklerinin Testi}

Psikolojik güvenlik, örgütsel performans ve örgütsel öğrenme ölçeklerini test etmek amaciyla, doğrulayıcı faktör analizi yapılmıştır (Ek 1).Psikolojik güvenlik, örgütsel performans ve örgütsel öğrenme değişkenlerine ait model uyum değerlerinden RMSEA, Ki-Kare/sd, AGFI, GFI model uyumluluğu için kabul edilebilir düzeyde değildir. Bu nedenle, analiz sonucu önerilen modifikasyonlar yapılmış, istatistiki bakımdan uygun olmayan psikolojik güvenlik değişkeninde yer alan PG4, PG6 ve PG7 önermeleri; örgütsel performans değişkeninde yer alan OPERF3 önermesi; örgütsel öğrenme değişkeninde yer alan ÖOGR4, OOGR5 ve OOGR6 önermeleri elenmiştir. Modifikasyon sonrası ölçekte yer alan değişkenlerin değerleri kabul edilebilir düzeyde gerçekleşmiştir.

\section{Hata Yönetimi Ölçeğinin Testi}

Hata yönetimi ölçeğini test etmek amacıyla, doğrulayıcı faktör analizi yapılmıştır (Ek 2). Doğrulayıcı faktör analizi sonuçlarına göre, hata yönetimi boyutlarında yer alan sekiz değişkenden hata yeterliliği, hatalardan risk alma ve hata iletişimi değişkenlerine ait tüm önermelerin model uyum değerlerinin kabul edilebilir düzeyde olduğu belirlenmiştir. Bu değişkenler modelle uyumluluk göstermiştir. Yapılan modifikasyon sonrasında da bu üç değişkende hiçbir önerme elenmemiştir.

Diğer değişkenler olan hatalardan öğrenme, hata gerginliği, hata tahmini, hataları örtbas etme ve hatalar hakkında düşünmeye ait model uyum değerlerinden RMSEA, Ki-Kare/sd, AGFI, GFI model uyumluluğu için kabul edilebilir düzeyde değildir. Bu nedenle analiz sonucu önerilen modifikasyonlar yapılmış, istatistiki bakımdan uygun olmayan hatalardan öğrenme boyutunda HOGR4 önermesi, hata gerginliği boyutunda HGERG4 ve HGERG5 önermesi, hata tahmini boyutunda HTAH2 öner- 
mesi, hataları örtbas etme boyutunda HORT1, HORT2 ve HORT6 önermeleri, hatalar hakkında düşünme boyutunda ise HAHD3 ve HAHD5 önermelerinden oluşan dokuz önerme elenmiştir. Sonuçlara göre; hata yönetimi boyutlarında yer alan değişkenlerin kabul edilebilirliği oldukça iyi düzeydedir.

\section{Araştırma Modelinin Testi}

\section{Hata Yönetimi Modelinin Yol Analizi}

Hata yönetimi modelinde yer alan ve analiz sonucu kalan değişkenler arasındaki ilişkiler Tablo2'de verilmiştir.

Tablodan da görüldüğü üzere, hata yönetimi; hata yeterliliği, hatalardan öğrenme, hatalardan risk alma, hataları örtbas etme, hata iletişimi ve hatalar hakkında düşünme boyutlarından oluşmuş, hata yönetimi modelinde yer alan diğer iki faktör olan hata gerginliği ve hata tahmini değişim (modifikasyon) sonrası hata yönetimi dışında kalmıştır. Dolay1sıla, H1a, H1b, H1c, H1f, H1g ve H1h hipotezleri kabul edilmiştir. H1d ve H1e hipotezleri desteklenmemiştir. Otel işletmelerinde hata yönetimi üzerinde hata yeterliliği, hatalardan öğrenme, hatalardan risk alma, hataları örtbas etme, hata iletişimi ve hatalar hakkında düşünmenin etkili olduğu görülmüştür. Hata yönetimi boyutlarından sadece hataları örtbas etme ile hata yönetimi arasında istatistiksel olarak olumsuz bir ilişki söz konusudur. Standart değerler ve $t$ değerlerine göre, hata yeterliliği ve hatalar hakkında düşünme hata yönetimi üzerinde daha etkili olan boyutlardır. Hata yönetimi faktörü için ele alınan boyutlardan hata gerginliği ve hata tahmini değişkenlerinin hata yönetimini etkilemediği saptanmıştır. Sonuç olarak, Kocaeli ve Sapanca'daki otel işletmelerinde hata yönetimi boyutları araştırma modelinde kullanılan Rybowiak ve diğerlerinin (1999) hata yönetimi modeline büyük oranda uygunluk göstermektedir.

Hata yönetimi modelinin Yol Diyagramı, Şekil 2'de gösterilmiştir.

\section{Araştırma Modelinin Yol Analizi}

Bu çalışmada, mutlak doğrulayıcı strateji kullanılarak, hata yönetimi modeli doğrulanmış, hata yönetimi ile psikolojik güvenlik, örgütsel performans ve örgütsel öğrenme arasındaki ilişkiler ortaya konulmaya çalışılmıştır. Analiz sonucunda 190,92 ki-kare değeri ve 115 serbestlik derecesinin birbirine oranı 1,66'dır. Artmalı uyum indeksinin (CFI) değeri 0,88 olup kabul edilebilirliği iyi düzeydedir. Düzeltilmiş iyilik indeksi (AGFI) 0,75 olup model uyumluluğu için önerilen değer olan 0,90 'dan küçük olduğu için yeterli değildir. RMSEA değeri 0,082 olup istatistiki olarak önerilen 0,08 değerinden büyük olduğu için bu değer kabul edilebilirlik için yeterli değildir. RMSR değeri 0,12'dir. Bu değerlere göre araştırma modeli kabul edilebilir düzeyde değildir. Analiz sonuçlarına göre önerilen modifikasyonlar yapılmış, modifikasyon öncesi ve sonrası model uyum değerleri Tablo 3'te gösterilmiştir.

Modifikasyon sonrası 72,21 ki-kare değeri ve 61 serbestlik derecesinin birbirine oran 1,18 olup önerilen 5 değerinden küçük olması nedeniyle kabul edilebilir düzeyde olduğu görülmektedir. Artmalı

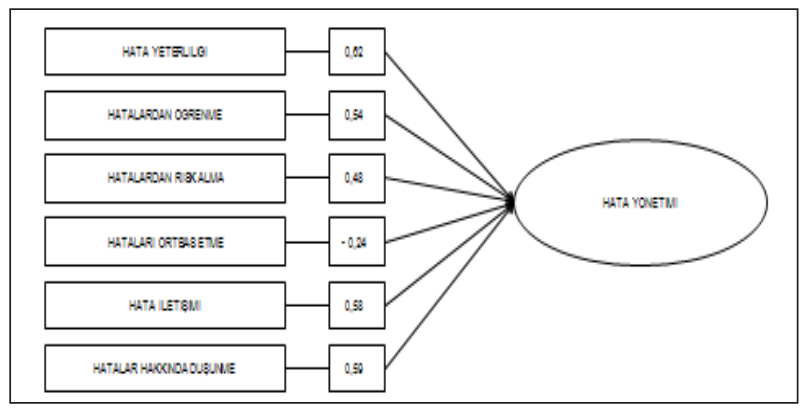

Şekil 2. Hata Yönetimi Modelinin Yol Diyagramı

Tablo 2. Modifikasyon Sonrası Hata Yönetimi Modeli Değişkenleri Arasındaki İlişkiler

\begin{tabular}{lcccr}
\hline Değişkenler & Standart Değer & $R 2$ & Hata Varyansı & $t$ Değeri \\
\hline Hata Yeterliliği- Hata Yönetimi & 0,62 & 0,38 & 0,25 & 5,56 \\
\hline Hatalardan Öğrenme- Hata Yönetimi & 0,54 & 0,29 & 0,46 & 4,83 \\
\hline Hatalardan Risk Alma- Hata Yönetimi & 0,48 & 0,23 & 0,49 & 4,26 \\
\hline Hataları Örtbas Etme- Hata Yönetimi & $-0,24$ & 0,058 & 0,66 & $-2,05$ \\
\hline Hata İletişimi- Hata Yönetimi & 0,58 & 0,34 & 0,33 & 5,21 \\
\hline Hatalar Hakkında Düşünme- Hata Yönetimi & 0,59 & 0,35 & 0,33 & 5,31 \\
\hline
\end{tabular}


Tablo 3. Araştırma Modelinin Uyum Değerleri

\begin{tabular}{lrrr}
\hline $\begin{array}{l}\text { Uyumluluk Indeksi } \\
\text { Mutlak Uyum Değeri }\end{array}$ & $\begin{array}{r}\text { Modifikasyon } \\
\text { Oncesi }\end{array}$ & $\begin{array}{r}\text { Modifikasyon } \\
\text { Sonrası }\end{array}$ & $\begin{array}{r}\text { Kabul } \\
\text { Edilebilir Uyum }\end{array}$ \\
\hline Ki-Kare & 190,92 & 72,21 & $1-5$ \\
\hline Serbestlik Derecesi & 115 & 61 & $0,90 \leq \mathrm{GFI} \leq 0,95$ \\
\hline Ki-Kare/sd & 1,66 & 0,18 & $0,85 \leq \mathrm{AGFI} \leq 0,90$ \\
\hline GFI & 0,82 & 090 & $0,05 \leq \mathrm{RMSR} \leq 0,08$ \\
\hline AGFI & 0,75 & 0,85 & $0,05 \leq \mathrm{RMSA} \leq 0,08$ \\
\hline RMSR & 0,12 & 0,091 & \\
\hline RMSEA & 0,082 & 0,043 & \\
\hline Artan Uyum Değeri & & & \\
\hline CFI & 0,88 & 0,85 & \\
\hline NNFI & 0,85 & 0,94 & 0,81 \\
\hline NFI & 0,76 & & \\
\hline
\end{tabular}

uyum indeksinin (CFI) değeri 0,85 olup kabul edilebilirliği iyi düzeydedir. Düzeltilmiş iyilik indeksi (AGFI) 0,85 olup model uyumluluğu için önerilen değerler arasındadır. RMSEA değeri 0,043 olup istatistiki olarak önerilen 0,08 değerinden küçük olduğu için model uyumluluğu için yeterli değerdedir. RMSR değeri 0,091'dir. Bu değerlere göre araştırma modeli kabul edilebilir düzeydedir. Yapılan yol analizine göre model için önerilen modifikasyonlar yapılmış ve istatistiki bakımdan uygun olmayan değişkenler elendikten sonra kalan değişkenler ve değerleri Tablo 4'te gösterilmiştir.

Sonuçlar; hata yönetimi ile örgütsel performans ve örgütsel öğrenme; psikolojik güvenlik ile örgütsel öğrenme, örgütsel performans ile örgütsel öğrenme değişkenleri arasındaki standart değerlerin olumlu olduğunu ve aynı değişkenler arasındaki t değerlerinin de olumlu olduğunu göstermektedir. En yüksek standart değer, hata yönetimi ile örgütsel performans arasında, en düşük standart değer ise örgütsel performans ile örgütsel öğrenme arasındadır. Hata yönetimi modeli üzerinde örgütsel performansın ve örgütsel öğrenmenin olumlu bir etkiye sahip olduğu görülmektedir. Buna göre, bu boyutların altındaki değişkenlere ait değerlerin yüksek çıkması otel işletmelerinde hata yönetimi anlayışının da yüksek olacağını göstermektedir. Sonuç olarak, örgütsel performans ve örgütsel öğrenme hata yönetimini etkilemektedir. Buna göre araştırma hipotezlerinden $\mathrm{H} 3, \mathrm{H} 4$ ve $\mathrm{H} 5$ hipotezleri kabul edilmiştir. Kocaeli ve Sapanca'da dört ve beş yıldızlı otel işletmelerinde hata yönetimi ile örgütsel öğrenme ve örgütsel performans arasında istatistiksel olarak olumlu yönde ilişki söz konusudur.

Araştırma modelindeki değişkenlerden sadece hata yönetimi ile psikolojik güvenlik arasındaki standart değer olumsuz çıkmıştır. Hata yönetimi üzerinde psikolojik güvenliğin olumsuz yönde etkili olduğu belirlenmiştir. Dolayısıyla, H2 hipotezi de kabul edilmiştir.

Yol analizinde önerilen modifikasyonlar doğrultusunda, kalan değişkenlere ait yol diyagramı Şekil 3'te gösterilmiştir (yol modelinde değişken puanlar1 standart değer tablosundan, ara değerler ise tahmini model değerlerinden alınmıştır).

\section{SONUÇ VE ÖNERILER}

Otelcilik sektöründe misafirlerin değişen beklentileri ve talepleri bu alanda rekabetin artmasına sebep olmaktadır. Bu rekabet yarışında avantaj kazanmak için yöneticilerin insan kaynaklarını daha etkin yönetmeleri gerekmektedir. Otelcilik sektöründe insan kaynakları öncelik gerektiren zor ve karmaşık bir faaliyet alanıdır. Yöneticilerin en temel sorunu çalışan- örgüt işbirliğinin sağlanarak çalışan motivasyonunun elde edilebilmesini sağlamaktır. İnsan kaynaklarının yönetim tarzı ve uygulamalarının misafir tatminini ve bağlılığını arttıracak şekilde olması gereklidir. Başarılı ve etkin otel yönetiminin temel amaçlarından biri de örgüt içinde çalışanların davranışlarının desteklenmesi ve motive edilmesidir. 
Tablo 4. Araştırma Modelinin Değişkenlerine Ait Değerler

\begin{tabular}{|c|c|c|c|c|c|}
\hline Değişkenler & $\begin{array}{l}\text { Standart } \\
\text { Değer }\end{array}$ & $R^{2}$ & $\begin{array}{c}\text { Hata } \\
\text { Varyansı }\end{array}$ & $\begin{array}{l}t \\
\text { Değeri }\end{array}$ & $\begin{array}{l}\text { Cronbach } \\
\text { Alpha }\end{array}$ \\
\hline Hata Yeterliliği & 0,57 & 0.32 & 0,28 & 5,56 & 0,75 \\
\hline \multicolumn{6}{|l|}{$\begin{array}{l}1 \text { Hata yaptığımda, bunun nasıl düzeltilebileceği } \\
\text { konusunda öneriler geliştirebilirim }\end{array}$} \\
\hline \multicolumn{6}{|l|}{$\begin{array}{l}4 \text { Hata yapabilmeme rağmen, bu hatayı yapmamaya } \\
\text { çalışıyorum }\end{array}$} \\
\hline Hatalardan Öğrenme & 0,51 & 0,26 & 0,48 & 4,83 & 0,78 \\
\hline \multicolumn{6}{|l|}{1 İşimi geliştirmek için hatalar bana yardımcı olur } \\
\hline \multicolumn{6}{|l|}{$\begin{array}{l}4 \text { Hatalarımdan edindiğim tecrübeler işimi daha iyi } \\
\text { yapmamda bana yardımcı olmaktadır. }\end{array}$} \\
\hline Hatalardan Risk Alma & 0,46 & 0,21 & 0,49 & 4,26 & 0,68 \\
\hline \multicolumn{6}{|l|}{$\begin{array}{l}1 \text { Bir kişi işini başarmayı istiyorsa, hata yapma riskini } \\
\text { de göze almak zorundadır }\end{array}$} \\
\hline \multicolumn{6}{|l|}{$\begin{array}{l}4 \text { Hiçbir şey yapmama yerine, hata yapmayı tercih } \\
\text { ediyorum }\end{array}$} \\
\hline Hataları Örtbas Etme & $-0,26$ & 0,070 & 0,65 & $-2,05$ & 0,66 \\
\hline \multicolumn{6}{|l|}{$\begin{array}{l}1 \text { Bir hata oluştuğunda müşteriye yansımamışsa, bu } \\
\text { hatayı açığa çıkarmanın yanlış olduğunu düşünüyorum }\end{array}$} \\
\hline \multicolumn{6}{|l|}{$\begin{array}{l}6 \text { Kendi hatalarını itiraf eden çalışanlar, büyük bir hata } \\
\text { yapmaktadır }\end{array}$} \\
\hline Hata Iletişimi & 0,63 & 0,40 & 0,30 & 5,21 & 0,72 \\
\hline \multicolumn{6}{|l|}{$\begin{array}{l}1 \text { Ben işyerinde bir hata yaptığım zaman, çalışma } \\
\text { arkadaşlarımın aynı hatayı yapmaması için konuyla } \\
\text { ilgili onlarla konuşurum }\end{array}$} \\
\hline \multicolumn{6}{|l|}{$\begin{array}{l}4 \text { Bir şeyleri yanlış yaptığım zaman, bu yanlışın } \\
\text { doğrusunu nasıl yapmalıyım diye çalışma } \\
\text { arkadaşlarıma sorarım }\end{array}$} \\
\hline Hatalar Hakkında Düşünme & 0,57 & 0,33 & 0,34 & 5,31 & 0,75 \\
\hline \multicolumn{6}{|l|}{$\begin{array}{l}1 \text { Hata yaptıktan sonra, bunun nasıl ortaya çıktığını } \\
\text { düşünürüm }\end{array}$} \\
\hline \multicolumn{6}{|l|}{$\begin{array}{l}5 \text { Hata sonrasında sebeplerini ve çözüm yollarını } \\
\text { dikkatlice düşünürüm }\end{array}$} \\
\hline Psikolojik Güvenlik & & & & & 0,63 \\
\hline $\begin{array}{l}3 \text { Otel çalışanlarımız ekibin çalışma sistemini } \\
\text { farklılaştırmak isteyenlerden hoşlanmazlar }\end{array}$ & 0,32 & 0,10 & 0,93 & 6,41 & \\
\hline 5 Bu otelde diğer çalışanlardan yardım istenmez. & 0,72 & 0,51 & 0,62 & 2,01 & \\
\hline Örgütsel Performans & & & & & 0,78 \\
\hline $\begin{array}{l}1 \text { Bu otel müşterilerinin beklentilerini karşılayabilen } \\
\text { bir oteldir. }\end{array}$ & 0,73 & 0,53 & 0,35 & 4,17 & \\
\hline 4 Bu otel daha iyi olmaya devam etmektedir & 0,87 & 0,75 & 0,30 & 1,88 & \\
\hline Örgütsel Öğrenme & & & & & 0,71 \\
\hline $\begin{array}{l}2 \text { Bu otelde bir kararı grup fikri olarak doğrudan } \\
\text { söylemek yerine bireylerin farklı görüşlerini dikkate } \\
\text { alma eğilimi vardır. }\end{array}$ & 0,66 & 0,44 & 0,53 & 6,06 & \\
\hline $\begin{array}{l}3 \text { Bu otelde çalışanlar, müşteriler ve otelin diğer } \\
\text { çalışanlarından bilgi elde etmeye çaba harcarlar. }\end{array}$ & 0,70 & 0,49 & 0,45 & 6,41 & \\
\hline $\begin{array}{l}7 \text { Sahip olduğumuz bilgilerle ilgili olarak etkileşimde } \\
\text { bulunmak için daima dışarıdan insanlarla müzakere } \\
\text { ederiz. }\end{array}$ & 0,68 & 0,46 & 0,51 & 6,22 & \\
\hline
\end{tabular}


Tablo 5. Araştırma Modeli Değişkenleri Arasındaki İlişkiler

\begin{tabular}{|c|c|c|c|c|}
\hline Değişkenler & Standart Değer & $R 2$ & Hata Varyansı & t Değeri \\
\hline Hata Yönetimi- Örgütsel Performans & 0,61 & 0,077 & 0,92 & 3,70 \\
\hline Psikolojik Güvenlik- Örgütsel Öğrenme & 0,34 & 0,077 & 0,92 & 2,03 \\
\hline Örgütsel Performans- Örgütsel Öğrenme & 0,30 & 0,092 & 0,91 & 2,24 \\
\hline Hata Yönetimi- Örgütsel Öğrenme & 0,036 & 0,0013 & 0,92 & 2,39 \\
\hline Hata Yönetimi- Psikolojik Güvenlik & $-0,54$ & 0,61 & 0,39 & $-1,98$ \\
\hline
\end{tabular}

Tablo 6. Hipotezlere İlişkin Analiz Sonuçları

\begin{tabular}{|c|c|c|}
\hline Hipotezler & İlişki Yönü & Sonuç \\
\hline H1a:: Hata yeterliliği hata yönetimi üzerinde etkilidir. & Olumlu ilişki & Desteklendi \\
\hline H1b::Hatalardan öğrenme hata yönetimi üzerinde etkilidir. & Olumlu ilişki & Desteklendi \\
\hline H1c::Hatadan risk alma hata yönetimi üzerinde etkilidir. & Olumlu ilişki & Desteklendi \\
\hline H1d:: Hata gerginliği hata yönetimi üzerinde etkilidir. & İlişki yok & Desteklenmedi \\
\hline H1e:: Hata tahmini hata yönetimi üzerinde etkilidir. & İlişki yok & Desteklenmedi \\
\hline H1f:: Hataları örtbas etme hata yönetimi üzerinde etkilidir. & Olumsuz ilişki & Desteklendi \\
\hline H1g: Hata iletişimi hata yönetimi üzerinde etkilidir. & Olumlu ilişki & Desteklendi \\
\hline H1h:: Hatalar hakkında düşünme hata yönetimi üzerinde etkilidir. & Olumlu ilişki & Desteklendi \\
\hline H2. Psikolojik güvenlik hata yönetimi üzerinde etkilidir. & Olumsuz ilişki & Desteklendi \\
\hline H3. Psikolojik güvenlik örgütsel öğrenme üzerinde etkilidir. & Olumlu ilişki & Desteklendi \\
\hline H4. Örgütsel performans örgütsel öğrenme üzerinde etkilidir. & Olumlu ilişki & Desteklendi \\
\hline H5. Örgütsel performans hata yönetimi üzerinde etkilidir. & Olumlu ilişki & Desteklendi \\
\hline
\end{tabular}

Çalışanların motivasyonunda sorun olduğunu gösteren en önemli göstergelerden biri de işgören devir oranının otel işletmelerinde daha yüksek olmasıdır. Bu sorun, işletmede maliyeti artırmanın

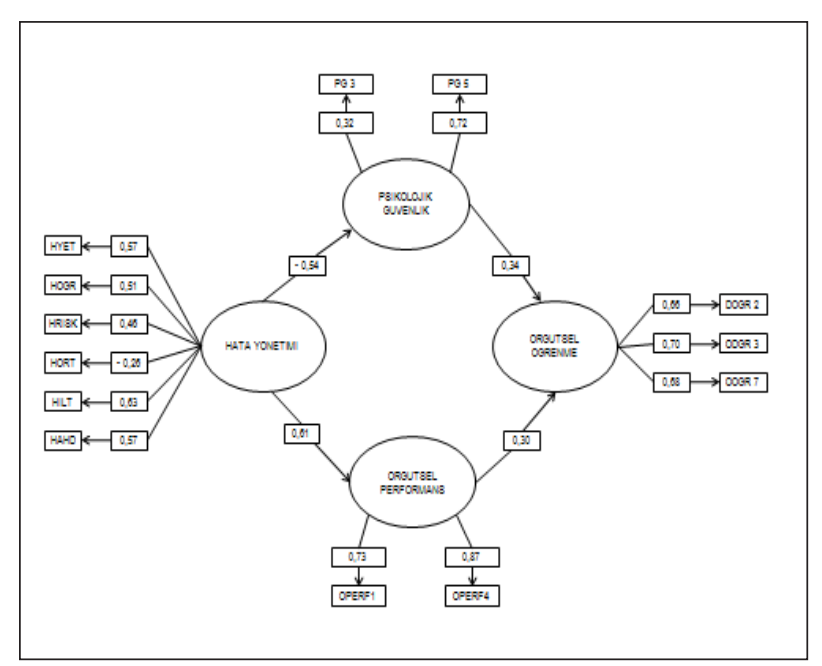

Şekil 3. Hipotezlere İlişkin Analiz Sonuçları yanı sıra, özellikle sürekliliğin öncelikte olduğu müşteri etkileşimi ile yoğun departmanlarda daha fazla önem taşımaktadır. Otel işletmeleri gibi sürekli dinamizmin olduğu bir ortamda personel değişikliği yerine, sahip olduğu bilgilerin yanı sıra her durumda öğrenmeye ve değişime açık çalışanlara sahip olmak çok daha değerlidir. Öğrenen birey, öğrendiği bilgileri sürekli işine yansıtır ve yaptığ 1 işten memnuniyeti de artar. Çalışanların öğrenen bireyler olması, öğrenmenin sağlanmasında etkili olan faktörleri bilmek ve bunları geliştirmek, öğrenmeyi olumsuz etkileyen unsurları gidermek için çalışmalarda bulunmak ise otel yöneticilerinin öncelikli amaçları arasındadır.

Özellikle hizmet sektöründe yer alan turizm işletmelerinde çalışanların hatalarından çıkarımlar yaparak, öğrenmenin gerçekleşmesi ile örgütsel etkinlik sağlanabilecektir. Bunu başarmanın yolu ise yöneticilerin çalışanlara uygun öğrenme ortamları sağlanmasına bağlıdır. Bu durum yöneticiler açısindan da büyük öneme sahiptir. Bunun en önemli 
sebebi dinamik bir ortamda faaliyet gösteren otel işletmesinde yöneticilerin sorunları çözümlemek yerine, zamanlarını ve enerjilerini daha çok asli görevleri için harcamalarına katkıda bulunmasıdır.

Araştırmada bağımsız değişken hata yönetimi ile bağımlı değişkenler olan psikolojik güvenlik, örgütsel performans ve örgütsel öğrenme arasında karşılaş̧ırma yapma ve faktörlerin birbirleriyle olan ilişkilerini ortaya koymak amaçlanmıştır. Araştırmada ayrıca hata yönetimini açıklayan boyutlar ile hata yönetimi sonucunda gerçekleşen öğrenme sürecinin hangi faktörlerin etkisinde gerçekleştiğini tespit etmeyi hedefleyen bu araştırmada, Kocaeli ve Sapanca örneklemi ile bir durum değerlendirmesi yapılmıştır.

\section{Kuramsal Çıktılar}

Yapılan analizler, çalışanların otel işletmelerinde hata yönetimi yaklaşımının var olduğunu düşündüklerini göstermektedir. Araştırma sonucunda hata yeterliliği, hatalardan öğrenme, hatalardan risk alma, hataları örtbas etme, hata iletişimi ve hatalar hakkında düşünme boyutlarının hata yönetimi üzerinde etkili olduğu saptanmıştır. Hataları örtbas etme ile hata yönetimi arasında istatistiksel olarak olumsuz yönlü bir ilişki bulunmuştur. Hataları örtbas etme, kendinden emin olmayan bireylerin veya hataya duyarlı çalışma ortamlarında (örneğin iş belirsizliği) bireyin uyum sağlama için geliştirdiği bir strateji olabilir. Genellikle hataları örtbas etme, düşük özsaygınlık, olumsuz duygusallık, kontrolün fazlalaşmasını kabul etmeme, girişim ruhunun az olmasının yanı sıra, kariyer stresi ve iş belirsizliği ile de ilişkilidir (Rybowiak vd. 1999). Araştırmanın gerçekleştirildiği otel işletmelerinde hata yönetimi ile bu boyut arasında olumsuz ilişkinin olması, çalışanların hata yönetimine ilişkin algılamaları arttıkça hataları örtbas etme eğiliminin azaldığını ortaya koymuştur.

Araştırma sonucunda hata yönetimi faktörlerinden hata gerginliği ve hata tahmini değişkenlerinin hata yönetimini etkilemediği saptanmıştır. Çalışanların hata yapmaktan, hataların oluşumundan korkmasını ve hatalara fazla duygusal tepki göstererek gergin olma durumunu ifade eden hata gerginliği boyutunun çalışanların hata yönetimi alg1lamalarını etkilemediği ortaya konmuştur. Böyle bir algının olması çalışanların olumsuz duygusallık, ruhsal rahatsızlıklar, depresyon, stres gibi psi- kolojik sorunlarının da olmasına sebep olabilecektir (Rybowiak ve diğerleri 1999). Sınırlı sayıda bir katılımcı ile gerçekleştirilmiş olmakla beraber bu bulgu, araştırmada çalışanların bu tür bir endişe ve kaygılarının olmadığını, daha motive bir şekilde iş yaptıklarını göstermesi açısından da önemlidir. Bireyin hata yapacağına ilişkin genel düşüncesini ifade eden hata tahmini bireyin olumsuz mizaçlı ve karamsar olmasını, aynı zamanda bireyin hatanın meydana gelebileceği durumları tahmin ederek bu durumlar karşısında gerçekçi olmasını da ifade etmektedir. Gerçekleştirilen araştırmada bu boyutun da hata yönetimini etkilemediği ortaya çıkmıştır. Bu durum, çalışanların böyle bir algılamalarının olmadığını göstermektedir. Hata gerginliği durumunda çalışanların özsaygıları ve iyimserliklerinin düşük olacağı beklenmektedir (Rybowiak vd.1999). Bu araştırmada hata tahmini boyutunun çalışanların hata yönetimi algılamalarını etkilemediği saptanmıştır. Yukarıda da ifade edildiği gibi araştırmanın sınırlı bir örneklemde yapılması sebebi ile bu bulguların daha geniş örneklemlerde de tekrar edilerek hata yönetimi boyutlarının geçerliliği test edilmelidir. Bu iki boyut dışında, araştırma alanı olarak belirlenen otel işletmelerinde hata yönetiminin diğer boyutlarının araştırma modelinde kullanılan model ile büyük oranda uygunluk gösterdiği saptanmıştır.

Yapılan analizlerde hata yönetimi ile örgütsel performans arasında yüksek derecede olumlu bir ilişkinin olduğu saptanmıştır. Araştırma, çalışanların hata sonrasında çıkarımlarda bulunarak, ne yapılacağına ilişkin analiz yapmaları durumunda örgütsel performanslarının da arttığını göstermektedir. Bu durum, araştırma alanındaki otellerde üst yönetim tarafından hatalara karşı etkili ve olumlu bir tutum sergilenmesi ile açılanabilir. Hatalar performansin olumsuz göstergelerinden biri olarak kabul edilemez. İssletmede hataların meydana gelmesine izin verilmeyen bir yönetim tarzı uygulandığında, işletmede sürekli kontrol sistemleri oluşturularak, risk almadan, her şey planlanmaya çalışılacaktır. Bu durum ise bir süre sonra işletmede işlerin yavaşlamasına ve hantallaşmasına sebep olacaktır (Peters 1987, akt. Rybowiak vd. 1999). Bu olumsuz ortamın oluşmasının önlenmesinde hatalara karşı olumlu bir tutumun izlenmesi büyük önem taşımaktadır. Araştırmadan elde edilen bulgular da araştırmanın gerçekleştirildiği otellerde 
hata yönetimi ile örgütsel performans arasında saptanan olumlu ilişki, hatanın performans sağlayıcı bir unsur olarak kullanıldığını ortaya koymuştur.

Örgütsel performans ve örgütsel öğrenmenin hata yönetimini olumlu etkilediği bulgusu alanyazında yapılan araştırma sonuçları (Dyck ve diğerleri 2005; Keith ve Frese 2005) ile aynı yönde gerçekleşerek, elde edilen bulguları desteklemiştir. Yapılan hataların performans artırılmasında bir firsat olarak değerlendirilmesi ve bunun öğrenmeye dönüştürülmesi işletmenin başarısı ve müşteri memnuniyetinin sağlanması açısından bir fırsattır. Müşteri memnuniyetinin arttırılması hem bölge otellerinin ve hem de bölgenin turizm gelişimi açısından son derece önem taşımaktadır.

Araştırma sonucunda hata yönetimi ile psikolojik güvenlik arasında istatistiksel olarak olumsuz yönlü bir ilişki saptanmıştır. Oysa kuramsal bölümde de ifade edildiği gibi hata yönetimi ile psikolojik güvenlik arasında olumlu yönlü bir ilişkinin olması beklenmektedir. Ancak bu ilişkinin araştırmada olumsuz yönlü çıkması çalışanların hatalarının açıklanmasından rahatsızlık duymaları ve kendilerini hataya olumlu yaklaşım sergileyen işletmelerde bile psikolojik olarak güvende hissetmediklerini göstermektedir. Çalışanların bu algılamalarını değiştirme yönünde üst yönetimlerin açıklamalarda bulunmaları, çalışanları yönlendirmeleri hatanın bir eksiklik değil, bir öğrenme fırsatı olduğunun çalışanlara anlatılması faydalı olacaktır. Bu konuda üst yönetimin desteği olmaksızın çalışanların bunu başarmaları ve algılarını değiştirmeleri mümkün değildir. Ayrıca, üst yönetimin bu konuda çalışanları destekleme yönünde tutum izlemeleri de önemlidir.

Otel işletmeleri, kaliteyi en üst seviyeye çıkarmak amacını taşırlar. Bu çalışmada ele alınan hata yönetimi yaklaşımının özünde de sunulan hizmette kaliteyi artırmak hedeflenir. Bu açıdan, hata yönetimi yaklaşımı ise diğer kalite yönetim yaklaşımları olan Toplam Kalite Yönetimi ve Altı Sigma yaklaşımı gibi yaklaşımlardan farklılıklar gösterdi-

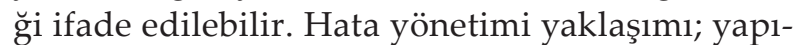
lan hatalardan elde edilen bilgileri ve deneyimleri işletme içinde tüm çalışanların paylaşmasına olanak sağlayarak, herkesin hatalarını konuşmasını, hatadan elde edilen bilgilerle örgütsel öğrenmeyi de sağlayarak hataları azaltmayı hedeflemektedir.

\section{Uygulamaya Yönelik Çıktılar}

Çalışmanın araştırma sonucunda ortaya koyduğu bulgular, otel yöneticileri açısından da önemli ipuçları vermektedir. Her şeyden önce, otel yöneticilerinin hataları önlemeden daha ziyade hata yönetimine odaklanmalarının daha yararlı olacağını göstermektedir. Araştırmada hata yönetimini etkileyen alt boyutlar bunu açık bir şekilde belirtmektedir. Otel yöneticilerinin, çalışanlarının hata yönetimi algılamalarını olumlu etkileyen konuların neler olduğunu bilmeleri, buna uygun olarak yönetim tarzlarını düzenlemeleri, birçok unsuru bu algılamaya göre şekillendirmeleri gerekmektedir. Üstelik çalışanın hata yönetimi algılamasının örgütsel performansı ve örgütsel öğrenmeyi de olumlu yönde etkilediği göz önüne alındığında konunun önemi daha iyi anlaşılacaktır.

Araştırmada hata yönetiminin örgütsel performansı ve örgütsel öğrenmeyi olumlu yönde etkilediği sonucuna ulaşılmıştır. Bu durum örgüt içinde hataların asla tamamen önlenebilir olmadığını kabul eden bir örgüt ikliminin yaygınlaşmasının çalışanların da hatalardan kazanım elde ederek, öğrenilebilecek bilgileri almalarına firsat sağlayacaktır.

Araştırmada ortaya çıkan bir başka önemli sonuç, hata yönetimi ile psikolojik güvenlik arasındaki istatistiksel olarak olumsuz ilişki durumudur. $\mathrm{Bu}$ sonuç, çalışanların hata yaptıklarında psikolojik olarak kendilerinin güvende hissetmediklerini göstermektedir. Bu sonuçtan hareketle, yöneticilerin ilk olarak hatalara tamamen açık bir yönetim tarzı sergilediklerini kabul etmeleri, bu tarz yönetimin uzun vadede örgüte daha çok yarar sağlayacağı$\mathrm{n}$ benimsemeleri gerekir. Aynı zamanda yönetim kademelerinde bulunanların örgütsel düzeyde hatalara açık yönetim tarzı geliştirmelerini ve bu açıklığın yaygınlaştırılarak tüm çalışanlara benimsetilerek, çalışanların psikolojik güvenlik algılamalarının yükselmesine olanak sağlayan hata yönetim yaklaşımlarını oluşturmaları gerektiğini ortaya çıkarmaktadır.

\section{Çalışmanın Kısıtları ve Gelecek Çalışmalara Öneriler}

Bu çalışma, Kocaeli ve Sapanca bölgesinde faaliyet gösteren otel işletmelerinde görev yapan çalışanlarla sınırlandırılmıştır. Ancak, araştırmaya katılmayı kabul eden işletme sayısının azlığı ve 
çalışmanın kısıtlı bir örneklem grubunda yapılmış olması çalışmanın en önemli kısıtını oluşturmaktadır. Bu durum, sonuçların evrenin tamamına genellenememesine sebep oluşturmuştur. Benzer ölçek kullanılarak farklı destinasyonlar itibariyle daha geniş örneklemlerde bu tür araştırmaların yürütülmesi zaman içinde konunun geliştirilmesine yardımcı olacaktır. Çalışmanın turizmde faaliyet gösteren diğer alt sektörlerde uygulanması, daha farklı ve sağlıklı yorumlarda bulunmaya katkıda bulunabilir. Ayrıca çalışmanın daha geniş bir örneklem grubuna uygulanması, genellenebilir ç1karımların yapılmasına da imkân verecektir.

Çalışmadaki anket formunda Rybowiak ve diğerleri (1999) tarafından geliştirilen hata yönetimi ölçeği ile Edmondson (1999) tarafından geliştirilen psikolojik güvenlik, örgütsel performans ve örgütsel öğrenme ölçeklerinden yararlanılmıştır. Ayrıca, farklı kültürler için geliştirilen ölçeklerin Türk kültürüne ait topluluklarda uygulanması ile yapılacak tespitlerin araştırma sonuçlarının geçerlilik ve güvenilirliklerini arttırabileceği düşünülmektedir.

\section{KAYNAKÇA}

Akbaba, A. (2008). Turizm İşletmelerinde Toplam Kalite Yönetimi. İçinde Turizm İşletmelerinde Çă̆daş Yönetim Teknikleri. (Editörler: F. Okumuş ve U. Avcı). Ankara: Detay Yayıncrlik, ss. 40-57.

Argyris, C. (1990). Overcoming Organizational Defences: Facilitating Organizational Learning. Prentice Hall, Englewood Cliffs, NJ.

Argyris, C. ve Schön, D. (1978). Organizational Learning: A Theory of Action Perspective. Addison-Wesley, Reading, M. A.

Arslantaş, C. (2006). Örgütsel Öğrenmenin Örgütsel Vatandaşlık Davranışı Üzerindeki Etkisini Belirlemeye Yönelik Görgül Bir Araştırma, Gazi Üniversitesi İktisadi ve İdari Bilimler Fakültesi Dergisi, 8 (3): 53-70.

Avc1, N. ve Küçükusta, D. (2009). Konaklama İşletmelerinde Örgütsel Öğrenme, Örgütsel Bağlılık ve İşten Ayrılma Eğilimi Arasındaki İlişki, Anatolia: Turizm Araştırmaları Dergisi, 20 (1): 33-44.

Avcı, U., Kılınç, İ. ve Okumuş, F. (2010). Öğrenme Düzeyleri Arası İlişki: Otel İşletmelerinde Bir Alan Araştırması, Ege Akademik Bakış, 10(1):95-115.

Avcı, U. ve Topaloğlu, C. (2008). Turizm İşletmelerinde Performans Ölçümü. İçinde Turizm İşlemelerinde Çă̆daş Yönetim Teknikleri. (Editörler: F. Okumuş ve U. Avcı). Ankara: Detay Yayincilik, ss. 337-369.

Avcı, U. (2005). İşletmelerde Örgütsel Öğrenme-Örgütsel Performans İlişkisi: Konaklama İşletmelerinde Örgütsel Öğrenme-Örgütsel Performans İlişkisine Yönelik İnceleme, (Yayımlanmamış Doktora Tezi), Süleyman Demirel Üniversitesi Sosyal Bilimler Enstitüsü.
Aydoğan, E. ve Deniz.G. (2013). Sosyo-Teknik Kolaylaştırıc1ların Bilgi Paylaşımı Ve Örgütsel Performans Üzerindeki Etkileri: Konaklama İşletmelerinde Bir Araştırma. 1. Örgütsel Davranış Kongresi Bildiriler Kitabı. (15-16 Kasim2013), Sakarya: 31-35.

Bentler, P. M. (1980). Multivariate Analysis with Latent Variables: Causel Modeling, Annual Review and Psychology, 31: 419-456.

Carmeli, A., Brueller, D. ve Dutton, J. E. (2009).Learning in the Workplace: The Role of High-Quality Interpersonal Relationships and Psychological Safety,Systems Research and Behavioral Science, 26: 81-98. Dorman, T. ve Frese, M. (1994). Error Training: Replication and the Function of Explaratory Behavior, International Journal of Human Computer Interaction, 6: 365-372.

DuBrin, A. (1986). Essentials of Management. NY: South-Western Publishing Co.

Dyck, C. V.,Frese, M., Baer, M. ve Sonnentag, S. (2005). Organizational Error Management Culture and Its Impact on Performance: A Two- Study Replication, Journal of Applied Psychology, 90 (6): 1228-1240.

Dwight, R. (1999). Searching for Real Maintenance Performance Measures, Journal of Quality in Maintenance Engineering, 5 (3): 258- 275.

Edmondson, A. C. (1999). Psychological Safety and Learning Behavior in Work Teams, Administrative Science Quarterly, 44 (2): 350-383.

Edmondson, A. C. (2003). Psychological Safety, Trust, and Learning in Organizations: A Group-Level Lens.http://citeseerx.ist.psu.edu/viewdoc/download?doi=10.1.1.195.4023Erep= rep1Etype $=p d f$, Erişim tarihi: 21 Mart 2013.

Ellis S, Caridi O, Lipshitz R. ve Popper, M. (1999).Perceived Error Criticality and Organizational Learning: An Empirical Investigation, Knowledge and Process Management, 6 (3): 166-175.

Eren, E. (2008). Örgütsel Davranış ve Yönetim Psikolojisi. İstanbul: Beta Basım Yayım Dağıtım A.Ş.

Esenkal, F. (2006). Kalite Yönetiminde Altı Sigma ve Otel İşletmelerinde Bir Uygulama Denemesi. (Yayımlanmamış Yüksek Lisans Tezi). Balıkesir Üniversitesi Sosyal Bilimler Enstitüsü.

Frese, M. (1991).Error Management or Error Prevention: Two Strategies to Deal with Errors in software Design. İçinde H.J. Bullinger (Editör). Human Aspects in Copmuting: Design and Use of Interactive Systems and Work with Terminals (ss.776-782). Amsterdam: Elsevier.

Frese, M. (1995).Error Management in Training: Conceptual and Empirical Results. İçinde C. Zucchermaglio, S. Bagnara ve S. Stucky (Editörler), Organizational Learning and Techonogical Change (ss.112-124). Berlin, Almanya: Springer Yayınları.

Genç, N. (2007). Yönetim ve Organizasyon: Çă̆daş Sistemler ve Yaklaşımlar. Gözden Geçirilmiş 3. Baskı. Ankara: Seçkin Yayıncilık.

Guchait, P., Kim,M. G. ve Namasivayam, K. (2011). Error Management at Different Organizational Levels - Frontline, Manager, and Company, International Journal of Hospitality Management, 31: 12-22. 
Guchait, P., Paşamehmetoğlu, A. ve Dawson, M. (2014). Perceived Supervisor and Co-Worker Support for Error Management:Impact on Perceived Psychological Safety and Service Recovery Performance, International Journal of Hospitality Management, 41: 28-37.

Güllülü, U. Erciş, A., Ünal, S., Bilgili, B. ve Gödekmerdan, L. N. (2008). Sigorta Hizmetlerinde Marka Değeri ve Marka Güveni. Ankara: Detay Yayıncilık.

Hair, J. F., Andersen, R. E., Tatham, R. L. ve Black, W. C. (1998). Multivariate Data Analysis. Beşinci Basım, Ed. NJ: Englewood Cliffs, Prentice- Hall.

Huber, G.P. (1991). Organizational Learning: The Contributing Processes and the Literatures, Organization Science, 2(1): 88-115.

Jones, C. F. ve O'Brien, J. (1991). Mistakes that Worked. New York: Bantam Books/Doubleday.

Jöreskog, K. G. ve Sorbom, D. (1973). Lisrel:8 Stuructural Equation Modeling with the Simplis Command Language. Chicago, IL: Scientific Software International, Inc.

Kahn, W. A. (1990). Psychological Conditions of Personal Engagement and Disengagement at Work, Academy of Management Journal, 33 (4): 692-724.

Keith, N. ve Frese, M. (2005). Self-Regulation in Error Management Training: Emotion Control and Metacognition as Mediators of Performance Effects, Journal of Applied Psychlogy, 69: 85-98.

Kiriş, G. (2003). 6 Sigma Yaklaşımı ve Tusaş Motor Sanayii A. Ş. (TEI)'de Uygulama Örneği. (Yayımlanmamış Yüksek Lisans Tezi). Anadolu Üniversitesi Sosyal Bilimler Enstitüsü.

Korsten, V. A., Stanz, K. J. ve Blignaut, J. (2004). The Development of a Management Error Orientation Questionnaire, Journal of Human Resource Management, 2 (1): 37-44.

Levitt, B. ve March, J. G. (1988). Organizational Learning, Annual Review Sociology, 14:319-340.

March, J. G. ve Olsen,J. P. (1975). The Uncertaintity of the Past: Organizational Learning under Ambiguity, European Journal of Political Research, 3: 147-171.

Mathieu, J. E., Goodwin, G. F.,Heffner, T. S.,Salas,T. S. ve Bowers,J. A. (2000). The Influence of Shared Mental Models on Team Process and Performance, Journal of Applied Psychology, 85: 273-283.

May, D. R., Gilson, R. L.ve Harter, L. (2004). The Psychological Conditions of Meaningfulness, Safety, and Availability and the Engagement of the Human Spirit at Work, Journal of Occupational and Organizational Psychology, 77: 11-37.

McCune, J. C. (1997). Making Lemonade, Management Review, 86: $49-53$.
Michael, D. N. (1976). On Learning to Plan and Planning to Learn. Jossey-Bass, San Francisco, C.A.

Nordstrom, C. R., Wendland, D. ve Williams, K. B. (1998). “To Err is Human": An Examination of the Effectiveness of Error Management Training, Journal of Business and Psychology, 12: 269-282.

Peters, T. (1987). Thriving on Chaos. Harper \& Row, New York.

Putz, D., Schilling, J., Kluge, A. ve Stangenberg, C. (2013). Measuring Organizational Learning from Errors: Development and Validation of an Integrated Model and Questionnaire, Management Learning, 44 (5): 511-536.

Rasmussen, J. (1982). Human Errors: A Taxonomy for Describing Human Malfunction in Industrial Installations, Journal of Occupational Accidents, 4: 311-335.

Reason, J. (1990). Human Error. Cambridge, İngiltere: Cambridge Üniversitesi Yayınları.

Rybowiak, V., Garst, H., Frese, M. ve Batinic, B. (1999). Error Orientation Questionnaire (EOQ): Reliability, Validity, and Different Language Equivalence, Journal of Organizational Behavior, 20: 527-547.

Schein, E.ve Bennis, W. (1965). Personal and Organizational Change through Group Methods. New York: Wiley.

Schein, E.H. (1993). How can Organizations Learn Faster? The Challenge of Entering The Green Room, Sloan Management Review, 34: 85-92.

Schein, E. (1985). Organizational Culture and Leadership. San Francisco: Jossey-Bass

Senders, J. W. ve Moray,N. P. (1991). Human Error: Case, Prediction, and Reduction. Hillsdale, NJ: Erlbaum.

Senge, P. M. (1990). The Fifth Discipline: The Art and Practice of the Learning Organization. Doubleday, New York.

Sitkin, S. B. (1992). Learning Through Failure: The Strategy of Small Losses. İçinde L. L. Cummings, B. M. Staw (Editörler). Research in Organizational Behavior, 14 JAl Press, Greenwich, C.T. (ss. 231-266).

Sitkin, S. B. (1996). Learning Through Failure: The Strategy of Small Losses. İçinde M. Cohen and U. Sproull (Editörler). Organizational Learning (ss.541-577). Thousand Oaks, CA: Sage.

Ural, A. ve Kılıç, İ. (2011). Bilimsel Araştırma Süreci ve SPSS ile Veri Analizi. Ankara: Detay Yayıncilik.

Yazıcıoğlu, Y. ve Erdoğan, S. (2004). SPSS Uygulamalı Bilimsel Araștırma Yöntemleri. Ankara: Detay Yayıncilık. 